Pesq. Vet. Bras. 35(6):583-589, junho 2015

DOI: $10.1590 / \mathrm{S} 0100-736 \mathrm{X} 2015000600017$

\title{
Macroscopic description of the external and middle ear of paca (Cuniculus paca Linnaeus, 1766) ${ }^{1}$
}

\author{
Leandro L. Martins ${ }^{2 *}$, Ijanete Almeida-Silva ${ }^{3}$, Maria Rossato ${ }^{3}$, Adriana A.B. \\ Murashima ${ }^{3}$, Miguel A. Hyppolito ${ }^{3}$ and Marcia R.F. Machado ${ }^{4}$
}

\begin{abstract}
Martins L.L., Almeida-Silva I., Rossato M., Murashima A.A.B., Hyppolito M.A. \& Machado M.R.F. 2015. Macroscopic description of the external and middle ear of paca (Cuniculus paca Linnaeus, 1766). Pesquisa Veterinária Brasileira 35(6):583-589. Departamento de Anatomia Animal, Escola de Veterinária, Universidade de Ingá, Rodovia PR-317 no 6114, Maringá, PR 87035-510, Brazil. E-mail: lmartins321@gmail.com

Paca (Cuniculus paca), one of the largest rodents of the Brazilian fauna, has inherent characteristics of its species which can conribute as a new option for animal experimantation. As there is a growing demand for suitable experimental models in audiologic and otologic surgical research, the gross anatomy and ultrastructural ear of this rodent have been analyzed and described in detail. Fifteen adult pacas from the Wild Animals Sector herd of Faculdade de Ciências Agrárias e Veterinárias, Unesp-Jaboticabal, were used in this study. After anesthesia and euthanasia, we evaluated the entire composition of the external ear, registering and ddescribing the details; the temporal region was often dissected for a better view and detailing of the tympanic bulla which was removed and opened to expose the ear structures analyzed mascroscopically and ultrastructurally. The ear pinna has a triangular and concave shape with irregular ridges and sharp apex. The external auditory canal is winding in its path to the tympanic mebrane. The tympanic bulla is is on the back-bottom of the skull. The middle ear is formed by a cavity region filled with bone and membranous structures bounded by the tympanic membrane and the oval and round windows. The tympanic membrane is flat and seals the ear canal. The anatomy of the paca ear is similar to the guinea pig and from the viewpoint of experimental model has major advantages compared with the mouse ear.
\end{abstract}

INDEX TERMS: Ear, paca, Cuniculus paca, rodent, temporal bone, ultrastructure.

RESUMO.- [Descrição macroscópica da orelha externa e media da paca (Cuniculus paca Linnaeus, 1766).] A paca (Cuniculus paca), um dos maiores roedores da fauna brasileira, possui características inerentes à sua espécie que podem contribuir como uma nova opção de animal experimental; assim, considerando-se que há crescente busca

\footnotetext{
${ }^{1}$ Received on April 2, 2014.

Accepted for publication on March 8, 2015.

${ }^{2}$ Departamento de Medicina veterinária, Universidade Estadual de Maringá, Campus de Umuarama, Estrada da Paca s/n, Bairro São Cristóvão, Umuarama, PR 87507-190, Brasil. *Corresponding author: Imartins321@gmail.com

${ }^{3}$ Departamento de Oftalmologia, Otorrinolaringologia e Cirurgia de Cabeça e Pescoço, Faculdade de Medicina de Ribeirão Preto, Universidade de São Paulo (USP), Av. Bandeirantes 3900, Ribeirão Preto, SP 14049-900, Brazil.

${ }^{4}$ Departamento de Morfologia e Fisiologia Animal, Universidade Estadual Paulista "Julio de Mesquita Filho" (Unesp), Campus de Jaboticabal, Via de Acesso Prof. Paulo Donato Castellane s/n, Jaboticabal, SP 14884-900, Brazil.
}

por modelos experimentais apropriados para pesquisas audiológicas e otológica cirúrgicas foram analisados e descritos em detalhes a anatomia macroscópica e ultraestrutural da orelha desse roedor. Para o estudo, utilizaram-se 15 animais adultos provenientes do plantel do Setor de Animais Silvestres da Faculdade de Ciências Agrárias e Veterinárias, Unesp-Jaboticabal, Jaboticabal/SP. Após anestesia e eutanásia, avaliou-se toda a composição da orelha externa, registrando-se e descrevendo-se os detalhes, também se dissecou a região temporal para melhor visibilização e detalhamento da bula timpânica e estas foram removidas e abertas a fim de expor as estruturas da orelha, as quais foram analisadas, macroscopicamente e ultraestruturalmente. 0 pavilhão auricular apresenta forma triangular e côncava com cristas irregulares e ápice pontiagudo; o conduto auditivo externo é sinuoso em seu trajeto até a membrana timpânica; a bula timpânica encontra-se na parte poste- 
rior-inferior do crânio; a orelha média é formada por uma região cavitária preenchida por estruturas ósseas e membranosas. É delimitada pela membrana timpânica e as janelas redonda e oval, sendo a membrana timpânica de forma plana e que veda todo o conduto auditivo. A anatomia da orelha da paca é semelhante à da cobaia e do ponto de vista de modelo experimental apresenta grandes vantagens em comparação com a orelha do rato.

TERMOS DE INDEXAÇÃO: Orelha, paca, Cuniculus paca, roedor, osso temporal, ultraestrutura.

\section{INTRODUCTION}

There is an increasing search for appropriate experimental models for the execution of otologic surgeries. Animal models are the most feasible alternative for otology research, especially in surgeries that require microscopic enlargement by involving delicate structures responsible for hearing such as the tympanic membrane and ossicular chain. Different experimental animal models are used such as chinchillas, guinea pigs, rats, cats, dogs, and monkeys, among others (Browning \& Granich 1978, Doyle \& Rood 1980, Hellstrom et al. 1982, Giebink et al. 1985, Van der Ven et al. 1999, Piltcher et al. 2002). Each of these animal species has advantages and disadvantages according to the purposes of the study.

Rats and guinea pigs are the animals most frequently used in otologic research. According to Judkins \& Li (1997), the use of guinea pigs in this type of study has advantages compared to rats. Also, some facility of handling and of manipulation and dissection of the guinea pig's cochlea has been observed. The bone fragility of the tympanic bulla of the rat favors its opening for the exposure of structures of the middle ear and cochlea, but also involves easy destruction when the temporal bone is removed (Albuquerque et al. 2009).

Guinea pigs and chinchillas are characterized as excellent study models when topical drugs are applied to the middle ear. However, the cost for the acquisition and maintenance of a sufficient number of chinchillas is very high, a fact that causes the use of this animal to be unviable. In contrast, guinea pigs are easy to maintain with proper care as recommended by the guidelines for the care and use of laboratory animals of the Institute of Laboratory Animal Resources, Comission on Life Sciences, National Research Council, National Academy Press, Washington, DC., 1996 (Wysocki 2005).

Swine and dogs are considered to be excellent models for otology experimentation but they require elaborate facilities with high maintenance costs (Damatta 2010).

Representing an alternative as experimental animals, the pacas, which are rodents, can become a good option for research purposes. The largest rodent in the Brazilian fauna (Matamoros 1982), the paca reaches $80 \mathrm{~cm}$ in body length and $12 \mathrm{~kg}$ in weight (Pachaly et al. 2001). With a mean survival time of 16 years, this rodent species is present in large part of the Brazilian territory (Lange \& Schmidt 2007, Queirolo et al. 2008).

Within this context, we considered it relevant to inves- tigate this animal as an experimental model for otologic research, focusing, on this occasion, on the description of the macroscopic anatomy of the external and middle ear of the paca.

\section{MATERIALS AND METHODS}

We used ten adult pacas culled for the selection and maintenance of equilibrium between males and females in the breeding stock of the Sector of Wild Animals, Department of Zootechny, Faculty of Agrarian and Veterinary Sciences (FCAV), Jaboticabal Campus, Unesp, registered with the Brazilian Institute of the Environment and Renewable Natural Resources (IBAMA) as a breeding site for specimens of the Brazilian fauna for scientific purposes (registration no. 482508).

The animals were euthanized with an overdose of midazolam ( $(1 \mathrm{mg} / \mathrm{kg}$ body weight) injected intramuscularly, plus a combination of ketamine hydrochloride $(20 \mathrm{mg} / \mathrm{kg}$ body weight) and xylazine hydrochloride $(1.5 \mathrm{mg} / \mathrm{kg})$ placed in the same syringe and injected intramuscularly.

After the verification of death, the animal was decapitated and the temporal region of the skull was dissected in order to describe the anatomical region and the insertion of the tympanic bulla. The temporal bone was opened with a surgical clamp positioned on the cervical spine up to the level of the tympanic bulla, which was located with the aid of the thumbs and then removed from the temporal bone.

To expose the cochlea, using the protocol of Albuquerque et al. (2009), we opened the bulla with the aid of a hemostatic clamp in the region of the posterior aerial sinus (mastoid) following its salience up to the petrous apex. The clamp was then positioned in the external auditory canal and the entire bony part was broken and raised.

The study was approved by the Animal Ethics and Well-Being Committee (CEBEA) of FCAV, Jaboticabal Campus, Unesp (protocol no. 004734-09) according to the Ethical Principles of Animal Experimentation adopted by the Brazilian College of Animal Experimentation (COBEA).

\section{RESULTS}

In paca the auricle is a mobile cartilaginous structure connected to the skull by skin, muscles and ligaments, with continuity through the external auditory canal up to the tympanic membrane. Its surface is covered with fine skin and hair. Because of its concave shape with irregular cristae and a pointed apex, it presents several regions with salient delimitations (Fig.1A,B). The auricle measures approximately $4.5 \mathrm{~cm}$ from base to apex.

The temporal bone is located in the posteorinferior region of the skull between the occipital bone caudally, the parietal bone dorsally and the frontal, palatine, sphenoid, maxillary end ethmoid bone rostrally. The tympanic bulla is located in the posteroinferior part of the skull (Fig.2). Squamous bone forms a process that joins a discrete zygomatic arch cranially fused with maxillary bone. It can be seen that this bone structure presents a region with an ivory-like aspect, with rugosities and areas of bone aeration (Fig.3A,B).

Located in a rostroventral direction at the base of the temporal bone, the tympanic bulla contains the tympanic cavity of the middle ear. The tympanic bulla forms the floor and large part of the lateral wall of the tympanic cavity, presenting a single cavity or multiple aerated bone spaces. 

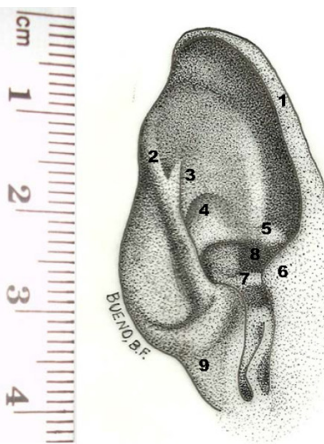

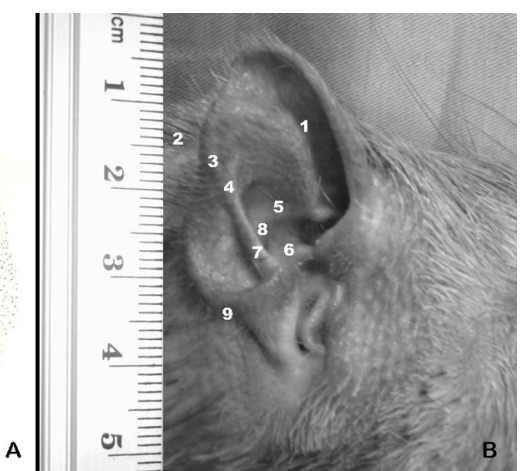

Fig.1. (A) Schematic drawing of the auricle of an adult paca (numbers corresponding to those of the figure on the side). (B) Photograph of the auricle of the paca showing the following structures: (1) Helix, (2) Antihelix, (3) Bridge, (4) Concha; (5) Supratragus, (6) Tragus, (7) Intertragic incisures, (8) External auditory canal, (9) Lobule.

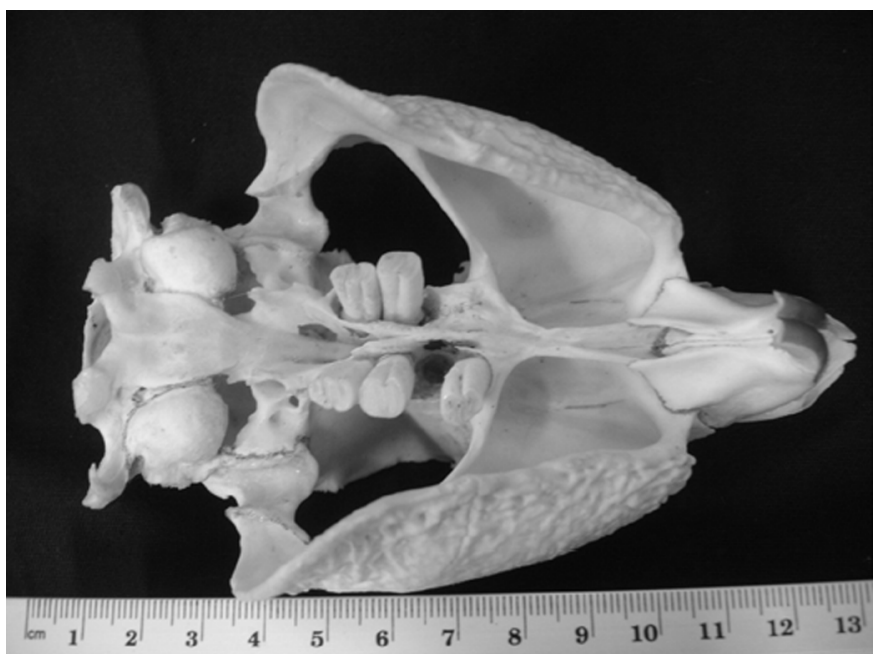

Fig.2. Skull of the paca, inferior view, with evidence of the location of the right and left tympanic bullae (circle).

The orifice of the external auditory canal (EAC), of a sinuous aspect, is identified in the cartilaginous portion of the ear of the paca. With the aid of a speculum it is possible to visualize the tympanic membrane and the malleus positioned almost vertically in relation to the membrane; the tympanic membrane seals the canal and delimits the end of the external ear. The regions located superiorly and laterally to the opening of the EAC present saliences, which are called anterior and posterior air sinuses, respectively. The bone saliences may be described as having the characteristics of alveolar bone.

The foramen of the facial nerve is located on the lateral surface inferior to the EAC, while the infratympanic foramen is found below the EAC (Fig.3B and 4A). The three orifices of the vestibular, cochlear and facial nerves are present in the medial portion of the tympanic bulla. The orifice of the cochlear nerve is the one of largest circumference located in the inferior medial portion in relation to the sagittal plane and in an anteroinferior position in relation to the coronal plane.

The inferior vestibular nerve is located close to the co-

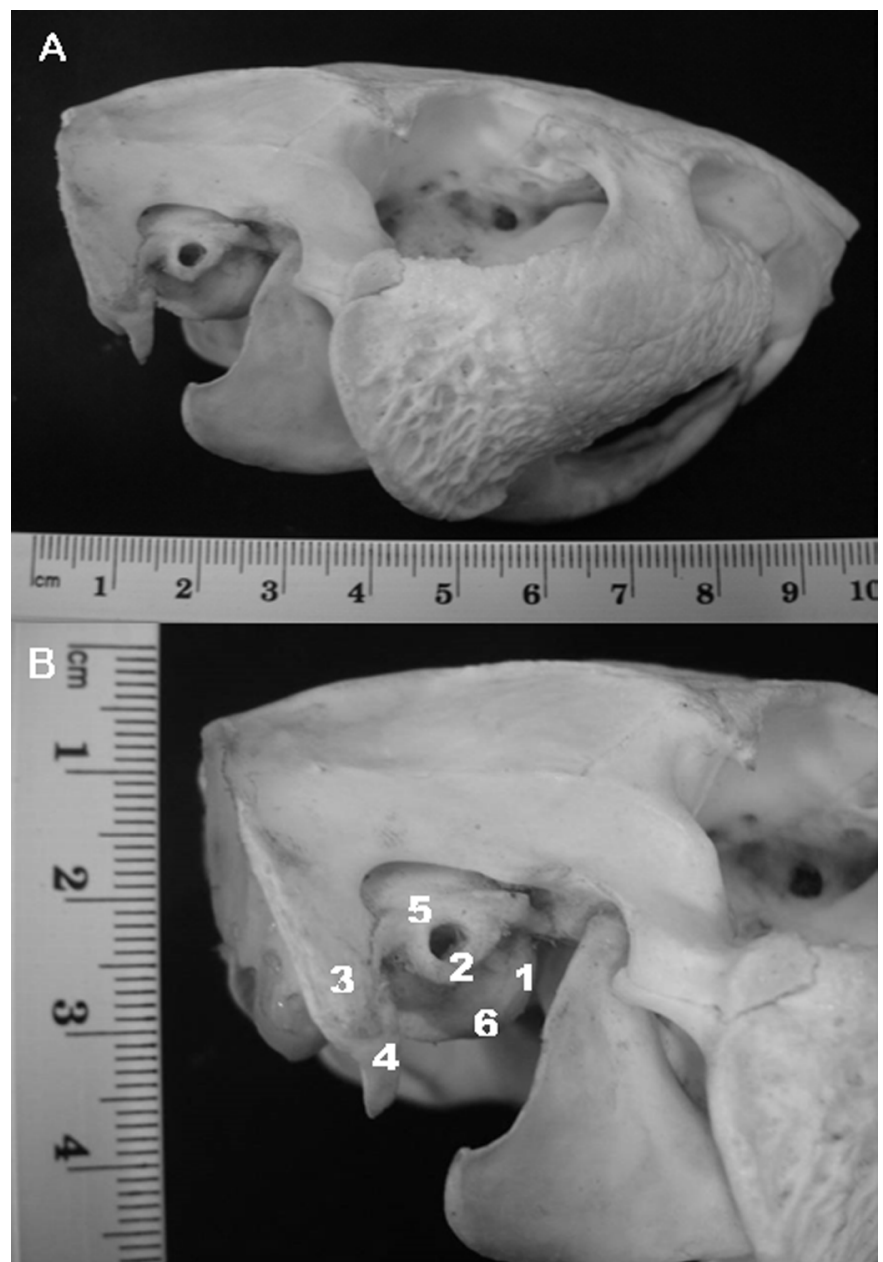

Fig.3. (A) The skull of paca, lateral view. (B) emphasis on the: (1) Tympanic bulla, (2) External auditory canal, (3) Squamous bone, (4) Paraoccipital apophysis, (5) Salience of the posterior air sinus, (6) Salience of the anterior air sinus.

chlear nerve, running posterolaterally to the latter, and the dorsal vestibular nerve is located posterolaterally to the facial nerve, which is located between the orifices of the dorsal and superior vestibular nerves (internal orifice of the facial canal). In the posterior extremity of the tympanic bulla the subarched fossa is vestigial and the foramen of the cerebellar artery is located inside it. Its region is delimited by the salience of the superior semicircular canal denoted arched eminence. The foramina of the vestibular, cochlear and facial nerves are located anteriorly. In the anterior extremity, the apex of petrous part of temporal bone has a rounded shape.

The orifice of the canal of the auditory tube is located in the apex of the tympanic bulla in the direction of the apex of petrous part of temporal bone (Fig.5B). The middle ear is formed by a cavitary region filled with osseous and membranous structures. It is delimited by the tympanic membrane and by the round and oval windows. Inside its bony walls it is possible to observe the epitympanic recess which is located dorsally to the EAC and the tympanic membrane. The tympanic membrane seals the entire auditory canal in a plane manner and the malleus handle and incus body, 


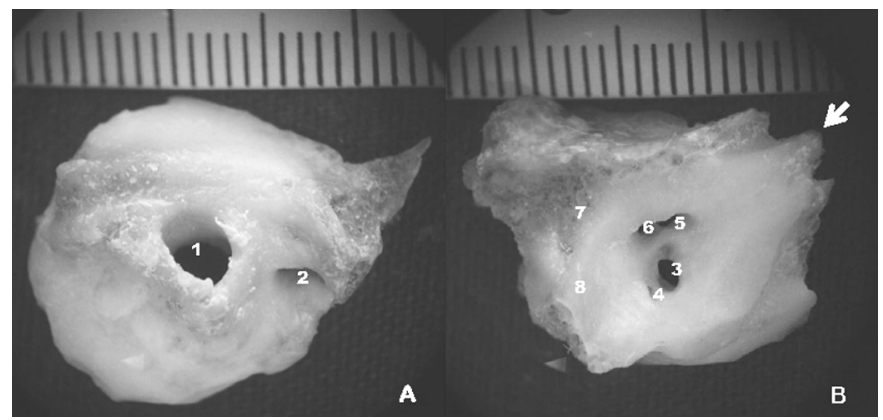

Fig.4. (A) The tympanic bulla of an adult paca; lateral view showing the following structures: (1) - External auditory canal, (2) External foramen of the facial nerve canal; 16x. (B) The tympanic bulla of an adult paca; medial view showing the following structures: (3) Foramen of the cochlear nerve, (4) Foramen of the inferior vestibular nerve, (5) Foramen of the facial nerve, (6) Foramen of the superior vestibular nerve, (7) Subarched fossa, (8) Arched eminence, Arrow = Projection of the auditory tube (apex of petrous part of temporal bone); 16x.

fused together to form the malleoincudal junction (fibrous articulation), are visualized projecting on the tympanic membrane. The malleus ossicle is attached to the tympanic membrane by means of its osseous prolongation, denoted malleus handle, and its major bone portion, denoted body, articulates with the incus (Fig.5A).

The bone prominences of the anterior and lateral semicircular canals can be observed in a medial and dorsal position and the horizontal segment of the facial nerve in its bone canal is visualized in a ventral position in relation to these prominences (Fig.5B). The osseous prominence between the oval and round windows, denoted promontory, is observed in the ventral region of the bulla delimiting the middle ear (Fig.5C). The incus, suspended by the suspensory ligament, presents a transversally plane body with a concave articular surface with which it joins the body of the malleus. The two extremities of this ossicle are denoted long process and short process of the incus. The long process of the incus is articulated with the head of the stapes by means of its lenticular surface (capitulum of the stapes). The short process or branch of the incus projects in the direction of the canal of the facial nerve (Fig.5B).

The stapes, located medially to the incus, consists of an extremity denoted stapedial head (capitulum) and two branches (anterior crus and posterior crus). These branches are fused to the platen of the stapes, a rounded region forming the base of this ossicle, conferring to it, together with the branches, a triangular shape (Fig.6A-C).

\section{DISCUSSION}

The location of the temporal bone and tympanic bulla in the paca resembles the descriptions of this organ in domestic animals (Nickel et al. 1979, Nomina Anatomica Veterinaria 2005, Dyce et al. 2010, König \& Liebich 2011), guinea pigs (Cooper \& Schiller 1975, Oliveira 1982, Wysocki 2005, Albuquerque et al. 2009), rats (Wysocki 2008, Albuquerque et al. 2009), and humans (Didio 1999, Grabowski \& Tortora 2002).

The squamous bone with an ivory-like aspect, with ru- gosities and regions of bone aeration observed in the paca is not detected in guinea pigs (Wysocki 2005, Albuquerque et al. 2009), rats (Wysocki 2008) or domestic animals. Also, in contrast to guinea pigs (Wysocki 2005, Albuquerque et al. 2009), rats (Wysocki 2008) and domestic animals (Ni-

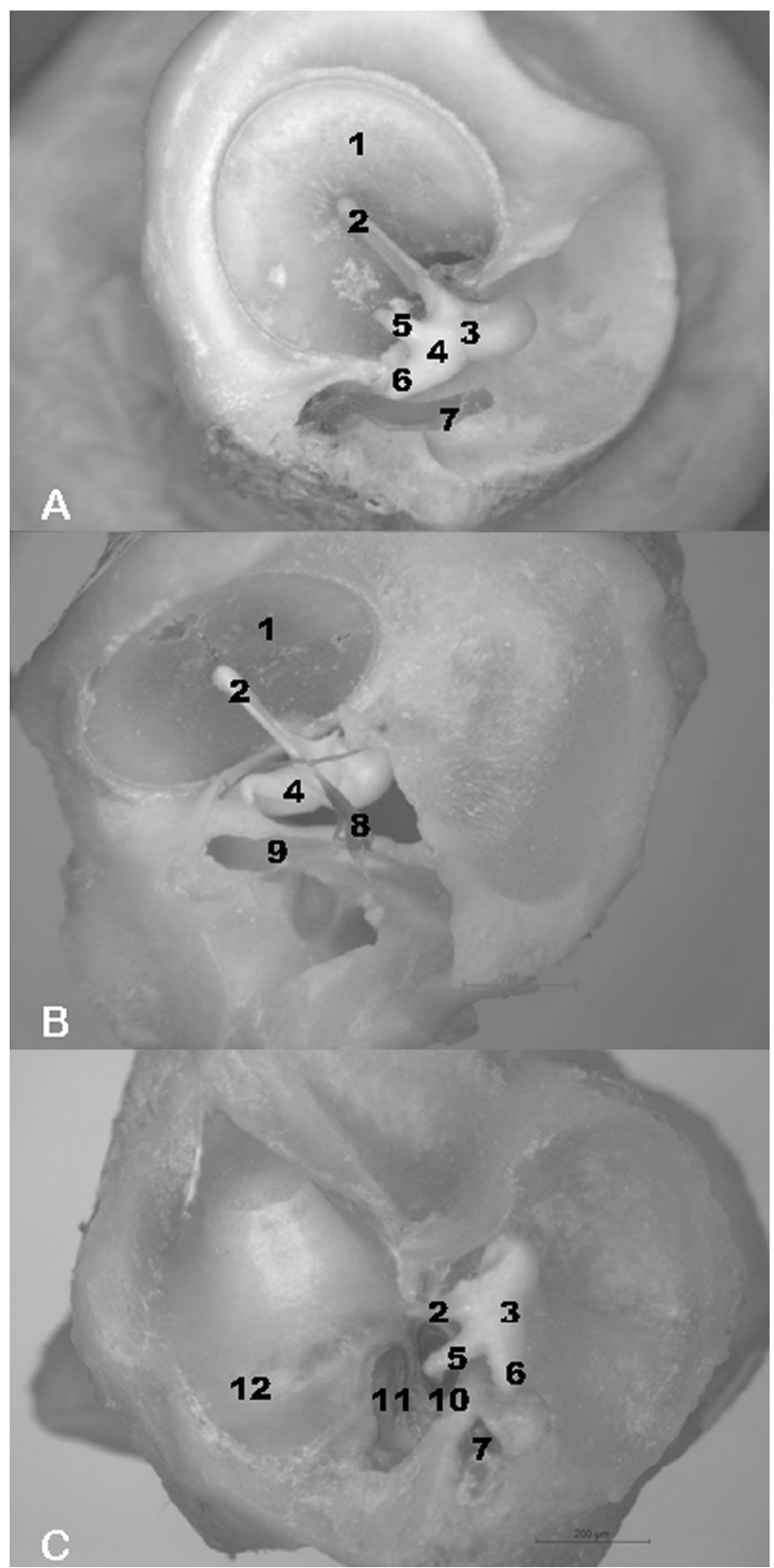

Fig.5. The middle ear of an adult paca. (A) (1) Tympanic membrane, (2) Malleus handle, (3) Malleoincudal junction, (4) Body of the incus, (5) Long branch of the incus, (6) Short branch of the incus, (7) Facial nerve; 16x. (B) (1) Tympanic membrane, (2) Malleus handle, (4) Body of the incus, (8) Tendon of the stapedial muscle, (9) Facial nerve canal; 16x. (C) (2) Malleus, (3) Malleoincudal junction, (5) Long branch of the incus, (6) Short branch of the incus, (7) Facial nerve, (10) Stapes, (11) Round window, (12) Cochlea (Promontory). 16x. 


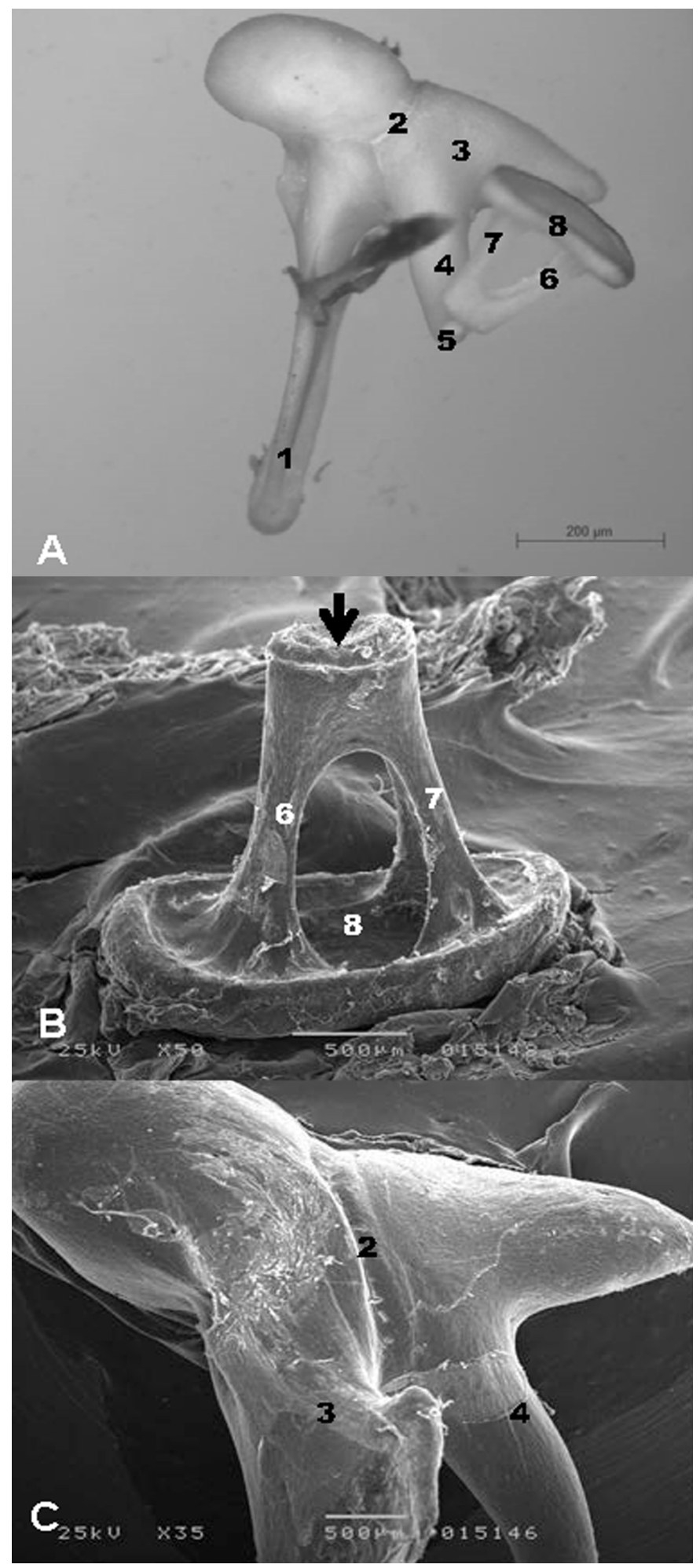

Fig.6. (A) Photograph of the ossicles of the middle ear of an adult paca showing the following structures. (1) Malleus handle, (2) Malleoincudal junction, (3) Body of the incus, (4) Long branch of the incus, (5) Incudostapedial joint, (6) Posterior crus of the stapes, (7) Anterior crus of the stapes, (8) Platen. (B,C) The middle ear ossicles of an adult paca showing the following structures: (6) Posterior crus of the stapes, (7) Anterior crus of the stapes, (8) Platen, Arrow = Lenticular process; (2) Malleoincudal junction, (3) Body of the incus, (4) Long branch of the incus; $35 \mathrm{x}$. ckel et al. 1979, Dyce et al. 2010, König \& Liebich 2011), the zygomatic arch of the paca is little developed. This fact is probably due to the feeding habits of these animals.

It can be seen that the lateral bony portion of the skull of the paca resembles the human temporal bone, preserving characteristics of osseous aeration, with aerated bone of the alveolar type (Grabowski \& Tortora, 2002), which are not observed in domestic animals (König \& Liebich 2011), rats (Wysocki 2008) or guinea pigs.

Despite the technical difficulty in the removal of the tympanic bulla of the paca due to its fixation to temporal bone, as also reported for guinea pigs compared to rats (Albuquerque et al., 2009), this rodent has advantages as an experimental model in surgical otologic procedures. These advantages involve the bodily characteristics of pacas regarding the physique and the similarity of its lateral bony portion to human temporal bone, especially regarding the characteristics of bone aeration (Grabowski \& Tortora 2002).

The constitution of the external ear of the paca is similar to that of most mammalian species (Cooper \& Schiller 1975, Nomina Anatomica Veterinaria 2005, Dyce et al. 2010, König \& Liebich 2011), especially regarding the presence of a concave cartilaginous structure with regions well delimited by its tortuous aspect. The presence of a lobule similar to that existing in humans is observed in this structure (Didio 1999, Grabowski \& Tortora 2002).

The tympanic bulla, in its semispherical format, presents the apex of petrous part of temporal bone (Wysocki 2005), with a rounded shape compared to that of the guinea pig (Goksu et al. 1992, Wysocki 2005, Albuquerque et al. 2009) and the rat (Albuquerque et al. 2009).

The external auditory canal of the paca resembles that described in most mammalian species (Cooper \& Schiller 1975, Nomina Anatomica Veterinaria 2005, Dyce et al. 2010, König \& Liebich 2011), with the possibility to visualize the tympanic membrane and the malleus handle with the aid of an auricular speculum (Nomina Anatomica Veterinaria 2005, Dyce et al. 2010, König \& Liebich 2011). The diameter of the external auditory canal can be compared to that of the guinea pig, but differs from that of the rat, which is wider. These anatomical characteristics contribute to advantages in surgical interventions in the middle ear (Albuquerque et al. 2009).

In the paca, as is also the case for all domestic species (Nomina Anatomica Veterinaria 2005, Dyce et al. 2010, König \& Liebich 2011), guinea pigs (Cooper \& Schiller 1975, Oliveira 1982) and humans (Grabowski \& Tortora 2002), the tympanic membrane seals the auditory canal and delimits the end of the external ear. This aspects represents an advantage of the paca over the rat, in which the greater exposure of the structures of the middle ear favors the frequent occurrence of otitis (Albuquerque et al. 2009), impairing the use of this animal in otologic experiments.

The tympanic bulla of the paca presents saliences described as aerial, anterior and posterior sinuses in its superior portion and in the portion lateral to the opening of the auditory canal, as also observe din the guinea pig (Wysocki 2005) and in the rat (Wysocki 2008). However, the charac- 
teristics of this region in the paca can be described as being similar to those of alveolar bone, a fact that makes this animal an experimental model with the same characteristics as those of humans.

The medial portion of the tympanic bulla of the paca does not differ from that of the guinea pig (Wysocki 2005) or the rat (Wysocki 2008) regarding the location of the orifices of the vestibular, cochlear and facial nerves. However, a vestigial subarched fossa is noted in the posterior extremity of this same portion that differs from the guinea pig (Wysocki 2005) and the rat (Wysocki 2008).

When the tympanic bulla is opened, the structures of the middle ear of the paca are exposed and therefore it is possible to visualize the ossicular chain, as is also the case for the guinea pig (Albuquerque et al. 2009, Oliveira 1982). In the rat, when the upper part of the bulla is removed, the malleus and incus come out together with the tympanic membrane, whereas the stapes remains over the oval window, as observed in the guinea pig and the paca. In the rat, the round window does not appear because it is covered by the carotid artery (Albuquerque et al. 2009). The round window is visualized in the paca as well as in the guinea pig.

The anatomy of the ossicles of the paca is similar to that of the guinea pig, although with a large difference in size. Both animals have the malleoincudal junction between the malleus and the incus (Albuquerque et al. 2009, Oliveira 1982). In guinea pigs, this characteristic is observed only in adult animals, since in the fetuses this region presents an articulation (Oliveira 1982). In rats, in turn, these ossicles are separated. Regarding the anatomical details of the ossicles, it is possible to compare pacas to guinea pigs especially regarding the shape of the stapes, a fact that does not occur in the rat, in which this ossicle has a rounded shape (Albuquerque et al. 2009).

The size of the structures of the ear of the paca represents an advantage of the use of this animal over guinea pigs and rats because it facilitates the microdissection and permits a better visualization of the details of the structures. Larger structures mainly facilitate access to regions of the ear with greater preservation of other structures. Albuquerque et al. (2009) reported that the tympanic bulla of the rat is very delicate and that bone fractures occur during manipulation of the structure for its opening. This characteristic of the paca is a highly positive point in surgeries of the middle ear since it facilitates access to and manipulation of structures in operations involving the tympanic membrane such as tympanoplasty for the treatment of conductive hearing loss and tinnitus (Lima et al. 2007), and the ossicular chain (Ribeiro et al. 2005).

\section{CONCLUSION}

The description of the macroscopic anatomy of the paca (Cuniculus paca) revealed anatomical features similar to the guinea pig and mouse.

The size of the animal facilitates the manipulation of the structures of the external and middle ear and thus provides advantages in studies with a variety of approaches, especially otological surgical procedures.
Acknowledgements.- To the Laboratory of Electron Microscopy, Department of Cellular and Molecular Biology and Pathogenic Bioagents, to the Laboratory of Experimental Surgery, Department of Surgery and Anatomy, Faculty of Medicine of Ribeirão Preto, and to the Laboratory of Anatomy, for technical assistance, and for financial support to FAPESP and CNPq.

\section{REFERENCES}

Albuquerque A.A.S., Rossato M., Oliveira J.A.A. \& Hyppolito M.A. 2009. Conhecimento da anatomia da orelha de cobaias e ratos e sua aplicação na pesquisa otológica básica. Revta Bras. Otorrinolaringol. 75:43-49.

Browning G.G. \& Granich M.S. 1978. Surgical anatomy ofthe temporal bone in the chinchilla. Ann. Otol. Rhinol. Laryngol. 87:875-882.

Cooper G. \& Schiller A. 1975. Anatomy of the Guinea Pig. Harvard University Press, Cambridge, MA. 417p.

Damatta R.A. 2010. Modelos animais na pesquisa biomédica. Scientia Medica 20:210-211.

Doyle W.J. \& Rood S.R. 1980. Comparison of the anatomy of the Eustachian tube in the Rhesus Monkey (Macaca mulatta) and man. Ann. Otol. 89:49-57.

Didio L.J.A. 1999. Tratado de Anatomia Aplicada. Póluss Editorial, São Paulo. $948 p$.

Dyce K.M., Sack W.O. \& Wensing C.J.G. 2010. Os órgãos dos sentidos, p.346352. In: Ibid. (Eds), Tratado de Anatomia Veterinária. 4aㅡ ed. Elsevier, Rio de Janeiro.

Giebink S., Ripley M.L., Shea D.A., Wright P.F. \& Paparella M.M. 1985. Clinical-histopathological correlations in experimental otitis media: implications for silent otitis media in humans. Pediatr. Res. 19:389-396.

Grabowski S.R. \& Tortora G.J. 2002. Princípios de Anatomia e Fisiologia. 9a ed. Guanabara Koogan, Rio de Janeiro, p.483-488.

Goksu N., Haziroglu R., Kemaloglu Y., Rarademir N., Bayramoglu I. \& Akyilddiz N. 1992. Anatomy of the guinea pig temporal bone. Ann. Otol. Rhinol. Laryngol. 101: 699-704.

Hellstrom S., Salen B. \& Stenfors L.E. 1982. Anatomy of the rat middle ear: a study under the dissection microscope. Acta Anat. (Basel) 112:346352.

Judkins R.F. \& Li H. 1997. Surgical anatomy of the rat middle ear. Otolaryngol. Head Neck Surg. 117:438-447.

König H.E. \& Liebich H.G. 2011. Anatomia dos Animais Domésticos. Vol.4. Artmed, São Paulo, p.613-628.

Lange R.R. \& Schmidt E.M.S. 2007. Rodentia: roedores silvestres (capivara, cutia, paca, ouriço), p.475-491. In: Cubas Z.S., Silva J.C.R. \& Catão-Dias J.A. (Eds), Tratado de Animais Selvagens: medicina veterinária. Roca, São Paulo.

Lima A.S., Sanchez T.G., Moraes M.F.B., Alves S.C.B. \& Bento R.F. 2007. Efeito da timpanoplastia no zumbido de pacientes com hipoacusia condutiva: seguimento de seis meses. Revta Bras. Otorrinolaringol. 73:384-389.

Matamoros Y. 1982. Notas sobre la biologia del tepezcuinte, Cuniculus paca, brisson, (Rodentia: Dasyproctidae) en cautiverio. Brenesia, San Jose, 19/20:71-82.

Nickel R., Schummer A. \& Seiferle E. 1979. The Viscera of the Domestic Mammals. Vol.2. Paul Parey, Berlin. 401p.

Nomina Anatomica Veterinária 2005. International Committee on Veterinary Gross Anatomical Nomenclature, Hannover. 5th ed. 66p.

Oliveira J.A.A. 1982. Contribuição ao estudo da anatomia do osso temporal da cobaia. Braz. J. Otorhinolaryngol. 48:7-12,

Pachaly J.S., Acco A., Lange R.R., Nogueira T.M.R., Nogueira M.F. \& Ciffoni E.M.G. 2001. Order Rodentia (rodents), p.225-237. In: Fowler M.E. \& Cubas Z.S. (Eds), Biology, Medicine and Surgery of South American Wild Animals. Blackwell, Oxford.

Piltcher O.B., Swarts M., Magnuson K., Alper C.M., Doyle W.J. \& Hebda P.A. 2002. A rat model of otitis media with effusion caused by Eustachian tube obstruction with and without Streptococcus pneumoniae infection: methods and disease course. Otolaryngol. Head Neck Surg. 126:490498. 
Queirolo D., Vieira E., Emmons L. \& Samudio R. 2008. Cuniculus paca. In: 2008 IUCN Red List of Threatened Species. Available at <www.iucnredlist.org> Access on 1 May 2009.

Ribeiro F.A.Q., Doria S. \& Almeida R. 2005. Fixação da prótese de estapedotomia à cadeia ossicular com cianoacrilato: relato de dois casos. Arq. Intern. Otor. 9:306-312.

Van der Ven L.T., Van den Dobbelsteen G.P., Nagarajah B., Van Dijken H.,
Dortant P.M., Vos J.G. \& Roholl P.J. 1999. A new rat model of otitis media caused by Streptococcus pneumoniae conditions and application in immunization protocols. Infect. Immun. 67:6098-6103.

Wysocki J. 2005. Topographical anatomy of the guinea pig temporal bone. Hear Res. 199:103-110.

Wysocki J. 2008. Topographical anatomy and measurements of selected parameters of the rat temporal bone. Fol. Morph. 67:111-119. 